\title{
A New Thioamide Derivative for Separation and Preconcentration of Multi Elements in Aquatic Environment by Cloud Point Extraction
}

\author{
Mohamed M. Hassanien ${ }^{1,2^{*}}$, Ali M. Hassan ${ }^{3}$, Wael I. Mortada ${ }^{4}$, Ahmed A. El-Asmy ${ }^{5}$ \\ ${ }^{1}$ Chemistry Department, Industrial Education College, Beni-Suef University, Beni-Suef, Egypt \\ ${ }^{2}$ Chemistry Department, Faculty of Science, Al-Jouf University, Saudia, Arabia \\ ${ }^{3}$ Chemistry Department, Faculty of Science, Al-Azhar University, Cairo, Egypt \\ ${ }^{4}$ Clinical Chemistry Department, Urology and Nephrology Center, Mansoura University, Mansoura, Egypt \\ ${ }^{5}$ Chemistry Department, Faculty of Science, Mansoura University, Mansoura, Egypt \\ E-mail: "mmhassanien2002@yahoo.com \\ Received May 27, 2011; revised July 20, 2011; accepted August 10, 2011
}

\begin{abstract}
2-(pyridine-2-yl)-N-p-chlorohydrazinecarbothioamide (HCPTS) was synthesized, characterized and successfully applied for the preconcentration of $\mathrm{Cu}(\mathrm{II}), \mathrm{Ni}(\mathrm{II}), \mathrm{Zn}(\mathrm{II}), \mathrm{Cd}(\mathrm{II}), \mathrm{Co}(\mathrm{II}), \mathrm{Pb}(\mathrm{II}), \mathrm{Fe}(\mathrm{II}), \operatorname{and} \mathrm{Hg}(\mathrm{II})$ in water, blood, and urine samples prior to graphite furnace atomic absorption determination (GFAAS); Hg was determined by cold vapor technique. Under the optimum experimental conditions (i.e. $\mathrm{pH}=8,10^{-4} \mathrm{M}$ of HCPTS, $0.05 \% \mathrm{w} / \mathrm{v}$ of Triton X-114), calibration graphs were linear in the range of 0.02 to $200 \mathrm{ng} \cdot \mathrm{mL}^{-1}$ for $\mathrm{Co}(\mathrm{II}), \mathrm{Cd}(\mathrm{II}), \mathrm{Pb}$ (II) and $\mathrm{Ni}(\mathrm{II}) ; 0.03$ to $200 \mathrm{ng} \cdot \mathrm{mL}^{-1}$ for $\mathrm{Cu}(\mathrm{II}) ; 0.07$ to $200 \mathrm{ng} \cdot \mathrm{mL}^{-1}$ for $\mathrm{Fe}(\mathrm{II})$ and $\mathrm{Zn}$ (II) and 0.02 to $150 \mathrm{ng} \cdot \mathrm{mL}^{-1}$ for $\mathrm{Hg}(\mathrm{II})$. The enrichment factors were $43,51,41,46,54,40,45$ and 52 for $\mathrm{Cu}(\mathrm{II})$, $\mathrm{Ni}(\mathrm{II}), \mathrm{Zn}$ (II), $\mathrm{Cd}(\mathrm{II}), \mathrm{Co}(\mathrm{II}), \mathrm{Pb}(\mathrm{II}), \mathrm{Fe}(\mathrm{II})$, and $\mathrm{Hg}(\mathrm{II})$, respectively. The limit of detection were found to be 0.019, 0.094, 0.0514, 0.052, 0.0165, 0.047, 0.068 and $0.041 \mathrm{ng} \cdot \mathrm{mL}^{-1}$ for $\mathrm{Cu}(\mathrm{II}), \mathrm{Ni}(\mathrm{II}), \mathrm{Zn}(\mathrm{II}), \mathrm{Cd}(\mathrm{II}), \mathrm{Co}(\mathrm{II})$, $\mathrm{Pb}$ (II), $\mathrm{Fe}(\mathrm{II})$, and $\mathrm{Hg}(\mathrm{II})$, respectively. The developed method was applied to the determination of these metal ions in water, blood and urine samples with satisfactory results.
\end{abstract}

Keywords: Heavy Metals, Preconcentration, Cloud Point Extraction, 2-(Pyridine-2-Yl)-N-P-Chlorohydrazinecarbothioamide

\section{Introduction}

Heavy metals are of the great importance for the life. Some of these such as $\mathrm{Cu}, \mathrm{Zn}, \mathrm{Co}, \mathrm{Fe}$ are essential to humans [1]. Others such as $\mathrm{Hg}, \mathrm{Cd}$ and $\mathrm{Pb}$ are toxic following occupational and environmental exposure [2]. Due to the low concentration of these metals in the environmental and biological samples and interfering effects, a preconcentration/separation technique is generally necessary prior to the determination. For this purpose, various analytical procedures have been used, such as adsorption on activated carbon $[3,4]$ co-precipitation $[5,6]$ column extraction $[7,8]$ ion-selective electrode $[9,10]$ liquid-liquid extraction (LLE) [11] and cloud-point extraction (CPE) [12-22].

CPE has attracted considerable attention mainly because it complies with the "Green Chemistry" principle
[23], as the amount of organic solvent is much less than that of traditional liquid extraction. Moreover, It is simple, cheap, highly efficient, fast, and of lower toxicity than those extractions that use organic solvents. This method has been applied for extraction and preconcentration of some metal ions such as $\mathrm{Cu}, \mathrm{Ni}, \mathrm{Co}$ and $\mathrm{Zn}$ in water samples [12], $\mathrm{Ag}, \mathrm{Zn}$, and $\mathrm{Pb}$ in environmental samples [13], Mo in sea water [14], Cd, Pb, Pd and $\mathrm{Ag}$ in environmental samples [15], $\mathrm{Cr}, \mathrm{Pb}, \mathrm{Cu}, \mathrm{Ni}, \mathrm{Bi}$, and $\mathrm{Cd}$ in environmental samples [16], $\mathrm{Cd}, \mathrm{Cu}, \mathrm{Co}$ and $\mathrm{Ni}$ in water [17], $\mathrm{U}, \mathrm{Th}, \mathrm{Zr}$ and $\mathrm{Hf}$ in aqueous samples [18], Be in water [19], $\mathrm{La}, \mathrm{Eu}$ and $\mathrm{Lu}$ [20], $\mathrm{Rh}$ [21] and $\mathrm{Yb}, \mathrm{Gd}$, $\mathrm{Eu}, \mathrm{Sm}, \mathrm{Sc}, \mathrm{Ho}$ in biological samples [22].

The cloud point is the temperature above which aqueous solutions of non-ionic and zwitter ionic surfactants become turbid. Specifically, above the cloud point the solution is separated into two phases: a rich phase con- 
taining a high surfactant concentration in a small volume and a poor phase with a surfactant concentration close to the critical micelle concentration [24,25]. CPE enables to avoid hazardous organic solvents and allows achieving a much higher concentration of recovered metal ions than in the case of liquid-liquid extraction, because the micellar phase volume is about 10 - 100-fold less than the volume of an aqueous phase [24]. Accordingly, any metal ions that either directly interact with micelles or after prerequisite binding with hydrophobic chelating ligand, can be extracted from the parent solution by CPE procedure. Trace elements can be extracted to the surfactant-rich phase usually after formation of a hydrophobic complex with an appropriate chelating agent [25]. The small volume of the surfactant-rich phase obtained with this methodology permits the design of extraction schemes that are simple, cheap, highly efficient, fast, and of lower toxicity than those extractions that use organic solvents.

Thiosemicarbazides constitute an important class of NS donors. The chemistry of these compounds was early explored [26] for their variable donor properties, structural diversity and biological applications. The coordination chemistry of a number of metal ions and a wide variety of complexes has been reported [27-29]. Thiosemicarbazides have been used for extraction and determination of some metal ions in biological and pharmacological samples [30-32]. In recent studies, 4-Ethyl-1-(pyridin-2-yl)thiosemicarbazide and its $\mathrm{Cu}(\mathrm{II})$ complexes with different anions have been synthesized and characterized [28] and used as a chelating agent for separation, preconcentration, and determination of $\mathrm{Cu}$ (II) ions in saturated saline solutions by a cloud point extraction technique [33]. In addition to, complexes of 4-ethyl and 4-(p-tolyl)-1-(pyridin-2-yl)thiosemicarbazides with Pd(II), $\mathrm{Pt}(\mathrm{II})$ and $\mathrm{Ag}(\mathrm{I})$ were synthesized and characterizes [29] These complexes show antibacterial activity to some Gram positive and Gram negative bacterial strains.

In the present study, we have developed and optimized a simple CPE-GF AAS methodology for multi-elements determination in water, blood and urine samples, which shows rapid and efficient performance. Copper(II), Ni (II), $\mathrm{Zn}(\mathrm{II}), \mathrm{Cd}(\mathrm{II}), \mathrm{Co}(\mathrm{II}), \mathrm{Pb}(\mathrm{II}), \mathrm{Fe}(\mathrm{II})$, and $\mathrm{Hg}(\mathrm{II})$ were preconcentrated using Triton X-114 in the presence of 2-(pyridine-2-yl)-N-p-chlorohydrazinecarbothioamide (HCPTS) (Structure 1) as a new chelating agent.

\section{Experimental}

\subsection{Reagents and Solutions}

All chemicals were of analytical-reagent grade and were used without previous purification (A.R. from Fluka, Aldrich or Merck). All solutions were prepared using

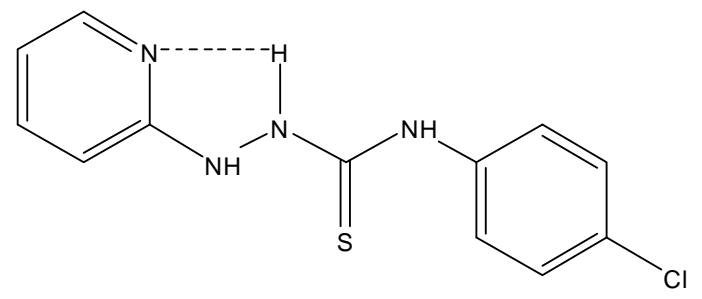

Structure 1. HCPTS.

double distilled water. Metal ion solutions (1000 mg/l) were prepared by dissolving appropriate amounts of the sulphates, chlorides or nitrates in double-distilled water. Working reference solutions were prepared daily by stepwise dilution from stock solution. Triton X-114 was used without further purification. HCPTS solution $(1 \times$ $10^{-3} \mathrm{M}$ ) was prepared by dissolving $0.0278 \mathrm{~g}$ in $100 \mathrm{~mL}$ distilled water. Buffers were used to control the $\mathrm{pH}$ of the solutions: hydrochloric acid-glycine ( $\mathrm{pH} 1$ - 3), hexamine-nitric acid ( $\mathrm{pH} 4$ - 8), ammonium chloride-am- monium hydroxide $(\mathrm{pH} \mathrm{9,10).} \mathrm{Solutions} \mathrm{of} \mathrm{alkali} \mathrm{metal} \mathrm{salts}$ $(1 \%)$ and various metal salts $(0.1 \%)$ were used in order to test the interference of anions and cations, respectively.

\subsection{Preparation of the Ligand}

HCPTS (Structure 1) was prepared by heating under reflux a mixture of 2-hydrazinopyridine $(0.1 \mathrm{~mol})$ and 4 chlorophenylisothiocyanate $(0.1 \mathrm{~mol})$ in $20 \mathrm{ml}$ absolute ethanol for $2 \mathrm{~h}$. On cooling, white fine crystals were formed, filtered off, washed with $\mathrm{EtOH}$ and $\mathrm{Et}_{2} \mathrm{O}$ and recrystallized from $\mathrm{EtOH}$ (m.p. $175^{\circ} \mathrm{C}$; yield $96 \%$ ). The purity of the compound was checked by TLC. Elemental analysis Calculated for $\mathrm{C}_{12} \mathrm{H}_{11} \mathrm{~N}_{4} \mathrm{SCl}$ : C 51.70, H, 3.98; N, 20.10.and the found: C, 51.23, H, 3.75; N, 19.92 .

\subsection{Apparatus}

Elemental analysis was carried out using a Perkin Elmer Elemental Microanalyser. Infrared spectrum of the ligand was measured using $\mathrm{KBr}$ discs on Mattson 5000 FTIR spectrometer. Calibration of the frequency reading was made with polystyrene film. The electronic spectrum of the ligand in DMF was recorded by Unicam UV-Vis spectrometer UV2 using $1 \mathrm{~cm}$ stoppered silica cells. Thermogravimetric analysis measurement (TG) of the ligand was performed using an automatic recording thermobalance type (951 DuPont instrument). Sample was subjected to heat using a rate of $10^{\circ} \mathrm{C} / \mathrm{min}$ from room temperature to $800^{\circ} \mathrm{C}$ in nitrogen flow. The mass spectrum of the ligand was recorded on $70 \mathrm{eV}$ with a Varian MAT 311 instrument. ${ }^{1} \mathrm{H}$ NMR spectrum of HCPTS, in $\mathrm{d}_{6}$-DMSO, was recorded on EM-390 (200 $\mathrm{MHz}$ ) spectrometer. 
GFAAS measurements were carried out using A Perkin Elmer atomic absorption spectrophotometer (Model Analyst 800) with a longitudinal Zeeman background correction furnished with a transversely heated graphite atomizer (THGA) was used for the determination of the metal ions, except Hg. Sample solutions were injected into the atomizer by using AS-800 autosampler. The sample injection volume was $20 \mu \mathrm{L}$ and the modifier " 5 $\mu \mathrm{g} \mathrm{Pd} / 3 \mu \mathrm{g} \mathrm{Mg}\left(\mathrm{NO}_{3}\right)_{2}$ " volume was $10 \mu \mathrm{L}$. The system is equipped with winLab 32 software. $\mathrm{Hg}$ was determined by cold vapor technique (CVAAS). The operating conditions are given in Tables $\mathbf{1}$ and $\mathbf{2}$.

The $\mathrm{pH}$ of the solution was adjusted using Hanna instrument model 8519 digital $\mathrm{pH}$ meter. A centrifuge with a model of CH90-2 (Hinotek Technology Co., Ltd. China) was used to accelerate the phase separation process.

\subsection{Procedure of CPE}

For the CPE, an aliquot of $50 \mathrm{~mL}$ of a solution containing metal ion buffered with $\mathrm{pH} 8$, Triton X-114 $(0.05 \%$ $\mathrm{w} / \mathrm{v}$ ) and $10^{-4} \mathrm{M}$ HCPTS were kept for $10 \mathrm{~min}$ in a thermostatic bath at $40^{\circ} \mathrm{C}$. Subsequently, separation of the phases was achieved by centrifugation for $10 \mathrm{~min}$ at $4000 \mathrm{rpm}$. The phases were cooled down in an ice bath in order to increase the viscosity of the surfactant rich phase. The bulk aqueous phase was easily decanted simply by inverting the tube and dried in water bath. The surfactant-rich phase in the tube was made up to $1 \mathrm{~mL}$ by adding absolute methanol/conc. $\mathrm{HNO}_{3}$ mixture (5:1).

\subsection{Preparation of Real Samples}

\subsubsection{Water Sample}

The water samples were filtered firstly through filter paper to separate the coarse particles and suspended matter and secondly through a Millipore cellulose nitrate membrane (pore size $0.45 \mu \mathrm{m}$ ), acidified to $\mathrm{pH} 2$ with $\mathrm{HNO}_{3}$ and stored in a refrigerator in a dark polyethylene bottle.

\subsubsection{Blood and Urine Samples}

One $\mathrm{mL}$ of blood or $5 \mathrm{~mL}$ of urine was digested with 6 $\mathrm{mL}\left[\mathrm{HNO}_{3}(65 \%)+\mathrm{HClO}_{4}(70 \%)\right](2: 1)$ in $50 \mathrm{~mL}$ beaker covered with a watch glass. The content of the beaker was heated gradually on a hot plate till dryness.

Table 1. Instrumental parameters and temperature program for metal ion analysis by GFAAS.

(a) Instrumental parameters:

\begin{tabular}{cccccccc}
\hline Parameter & Cu(II) & Ni(II) & Zn(II) & Cd(II) & Co(II) & Pb(II) & Fe(II) \\
\hline Wavelength (nm) & 324.8 & 232 & 213.9 & 228.8 & 242.5 & 283.3 & 248.3 \\
Slit width (nm) & 0.7 & 0.2 & 0.7 & 0.7 & 0.7 & 0.7 & 0.7 \\
Lamp current (mA) & 25 & 20 & 25 & 12 & 15 & 25 & 25 \\
\hline
\end{tabular}

(b). Temperature program:

\begin{tabular}{|c|c|c|c|c|c|c|c|c|c|c|}
\hline \multirow{2}{*}{ Step } & \multicolumn{7}{|c|}{ Temperature $\left({ }^{\circ} \mathrm{C}\right)$} & \multicolumn{2}{|c|}{ Time (s) } & \multirow{2}{*}{ Argon flow rate $\mathrm{ml} / \mathrm{min}$} \\
\hline & $\mathrm{Cu}(\mathrm{II})$ & $\mathrm{Ni}(\mathrm{II})$ & $\mathrm{Zn}(\mathrm{II})$ & Cd(II) & Co(II) & $\mathrm{Pb}(\mathrm{II})$ & $\mathrm{Fe}(\mathrm{II})$ & Ramp & Hold & \\
\hline Drying 1 & & & & 110 & & & & 1 & 30 & 250 \\
\hline Drying 2 & & & & 130 & & & & 15 & 30 & 250 \\
\hline Pyrolysis & 1200 & 1100 & 700 & 500 & 1400 & 850 & 1400 & 15 & 20 & 250 \\
\hline Atomization & 2000 & 2300 & 1800 & 1500 & 2400 & 1600 & 2100 & 0 & 6 & 0 \\
\hline Cleaning & & & & 2500 & & & & 1 & 5 & 250 \\
\hline
\end{tabular}

Table 2. Instrumental parameters for the determination of Hg by CVAAS.

\begin{tabular}{cc}
\hline Source & Hg hollow cathode lamp. \\
\hline Slit width $(\mathrm{nm})$ & 0.7 \\
Carrier gas flow rate $(\mathrm{ml} / \mathrm{min})$ & 1000 \\
Reducing agent & $1 \% \mathrm{~m} / \mathrm{v} \mathrm{NaBH}$ in $0.05 \% \mathrm{~m} / \mathrm{v} \mathrm{NaOH}$ \\
\hline
\end{tabular}


All heating steps were carried out under a hood with necessary precautions. After increasing the $\mathrm{pH}$ to about 3 using $1 \mathrm{M} \mathrm{NaOH}$, the volume was completed to $10 \mathrm{~mL}$ volumetric flask. Aliquots of $5 \mathrm{~mL}$ of the digested samples were analyzed according to the prescribed procedure.

\section{Result and Discussion}

\subsection{Characterization of the Ligand (HCPTS)}

The IR spectrum of HCPTS exhibits characteristic bands at 3262,3172 and $3131 \mathrm{~cm}^{-1}$ attributed to $v\left(\mathrm{~N}^{4} \mathrm{H}\right), v\left(\mathrm{~N}^{1} \mathrm{H}\right)$ and $v\left(\mathrm{~N}^{2} \mathrm{H}\right)$, respectively [28]. The $v(\mathrm{C}=\mathrm{N})_{\mathrm{Py}}$ appearing as a strong band at $1598 \mathrm{~cm}^{-1}$. The appearance of the $(\mathrm{C}=\mathrm{N})_{\mathrm{Py}}$ and $\mathrm{N}^{2} \mathrm{H}$ at lower values suggests intramolecular hydrogen bonding [29]. Also, two bands at 1512 and $1450 \mathrm{~cm}^{-1}$ were observed and assigned to thioamide I and III, respectively. Moreover, two sharp bands at 783 and $723 \mathrm{~cm}^{-1}$ were attributed to $v(\mathrm{C}=\mathrm{S})$ and $\rho(\mathrm{NH})$ [28]. The absence of any band due to $v(\mathrm{SH})$ in the range 2500 $2600 \mathrm{~cm}^{-1}$ [28] indicated that the ligand exists in the thione form.

The absorption spectrum of HCPTS in DMF showed a band at $35,714 \mathrm{~cm}^{-1}$ and three shoulders at 31,250, 24,390 and $23,148 \mathrm{~cm}^{-1}$ attributing to $\left(\pi \rightarrow \pi^{*}\right)_{\mathrm{Py}},\left(\pi \rightarrow \pi^{*}\right)_{\mathrm{C}=\mathrm{S}}$, $\left(\mathrm{n} \rightarrow \pi^{*}\right)_{\mathrm{Py}}$ and $\left(\mathrm{n} \rightarrow \pi^{*}\right)_{\mathrm{C}=\mathrm{S}}[29]$ transitions, respectively.

The TGA curve of HEPTS indicates a thermal stability till $167^{\circ} \mathrm{C}$ coincident with its melting point $\left(175^{\circ} \mathrm{C}\right)$. The curve showed two decomposition steps. The first from 167 to $219^{\circ} \mathrm{C}$ is corresponding to the loss of $\mathrm{C}_{5} \mathrm{H}_{4} \mathrm{~N}$ and $\mathrm{ClC}_{6} \mathrm{H}_{4}$ (Found 68.2\%; Calcd. 68\%), the second from 219 to 347 is attributed to the loss of $\mathrm{N}_{3} \mathrm{H}_{3}$ (Found $15.9 \%$, Calcd. 16.1\%), leaving a residue of $\mathrm{C}+\mathrm{S}$ (Found $15.9 \%$, Calcd. 15.8\%).

The ${ }^{1} \mathrm{H}$ NMR spectrum of HCPTS in $\mathrm{d}_{6}$-DMSO showed signals due to the protons of the phenyl and pyridine [29]. The three singlet signals at 8.54, 9.79 and 9.91 ppm are attributed to the $\mathrm{N}^{2} \mathrm{H}, \mathrm{N}^{1} \mathrm{H}$ and $\mathrm{N}^{4} \mathrm{H}$ protons, respectively. The $\mathrm{N}^{2} \mathrm{H}$ signal appears in the aromatic region confirming an intramolecular $\mathrm{H}$-bond. The other $\mathrm{NH}$ protons are shifted up field due to the inductive effect of pyridyl and phenyl rings as electron donor groups [29].

The mass spectrum of HCPTS shows the final peak at $280 \mathrm{amu}\left[\left(\mathrm{C}_{12} \mathrm{H}_{11} \mathrm{~N}_{4} \mathrm{SCl}\right)\right.$, calculated molecular weight $278.76 \mathrm{amu}$ ], and other peaks at 171, 111 and $77 \mathrm{amu}$ may correspond to various fragments. The peak described at $171 \mathrm{amu}$ is assigned to the fragment $\left[\mathrm{C}_{7} \mathrm{H}_{5} \mathrm{NSCl}\right]^{+}$, corresponding to the loss of $\left[\mathrm{C}_{5} \mathrm{H}_{6} \mathrm{~N}_{3}\right]^{+}$. The peak at 111 is corresponding to the fragment $\left[\mathrm{C}_{6} \mathrm{H}_{4} \mathrm{Cl}\right]^{+}$, corresponding to the loss of $[\mathrm{CHNS}]^{+}$fragment. Peak at 77 represent the fragment $\mathrm{C}_{6} \mathrm{H}_{4}$ with the loss of $\mathrm{Cl}$.

\subsection{Effect of pH on CPE}

The formation of metal complexes and its stability are important factors for the CPE. The $\mathrm{pH}$ plays a unique role on metal chelate formation and subsequent extraction. The extraction depends on the $\mathrm{pH}$ at which complex formation occurs. The effects of the $\mathrm{pH}$ on the percentage extraction recovery of $\mathrm{Co}(\mathrm{II}), \mathrm{Hg}(\mathrm{II}), \mathrm{Cd}(\mathrm{II}), \mathrm{Fe}(\mathrm{II})$, $\mathrm{Pb}(\mathrm{II}), \mathrm{Ni}(\mathrm{II}), \mathrm{Zn}(\mathrm{II})$ and $\mathrm{Cu}(\mathrm{II})$ were investigated at different $\mathrm{pH}(1-10)$. Where the percentage extraction recovery is the percentage of the concentration of metal found in spiked sample to the actual concentration. The results are shown in Figure 1. It was observed that $\mathrm{Pb}$ (II) and $\mathrm{Cu}(\mathrm{II})$ were extracted quantitatively $(>95 \%)$ at $\mathrm{pH} 5$; $\mathrm{Co}(\mathrm{II}), \mathrm{Ni}(\mathrm{II})$ and $\mathrm{Zn}$ (II) at $\mathrm{pH} 6$; $\mathrm{Hg}$ and $\mathrm{Fe}(\mathrm{II})$ at $\mathrm{pH}$ 7; $\mathrm{Cd}$ (II) $\mathrm{pH}$ 8. At lower $\mathrm{pH}$ values, the extraction is not quantitative, and at higher $\mathrm{pH}$ values, the hydrolysis of cations occurs except for $\mathrm{Co}$ and $\mathrm{Cd}(\mathrm{II})$ a result, $\mathrm{pH} 8$ was chosen as the working $\mathrm{pH}$ for the multi determination of these metals.

\subsection{Effect of HCPTS Concentration}

The extraction recoveries of the metals depend on the concentrations of the chelating agent. In order to select the optimum concentrations of HCPTS, the effects of the concentration of the HCPTS on the recoveries were investigated in the range of $1 \times 10^{-5}$ to $1.6 \times 10^{-4} \mathrm{M}$; the results are shown in Figure 2. For all metals, the maximum recoveries were obtained at $10^{-4} \mathrm{M}$ of HCPTS. Therefore, these concentrations were selected as the optimum concentration of the chelating agent.

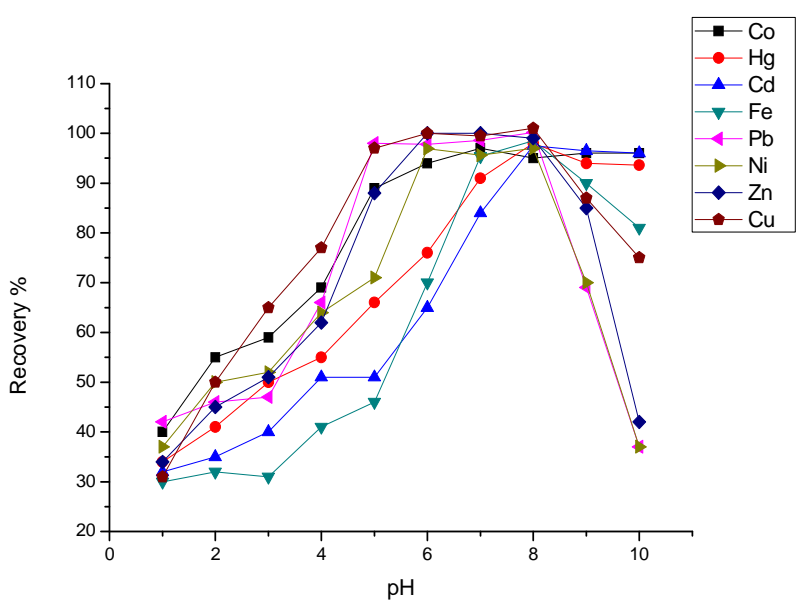

Figure 1. Influence of the $\mathrm{pH}$ on the recovery of extraction for the metal ions. Conditions: $10 \mathrm{ng} \cdot \mathrm{mL}^{-1}$ each metal; 50 $\mathrm{mL}$ cold aqueous solution; $10^{-4} \mathrm{~mol} \cdot \mathrm{L}^{-1}$ of the ligand; $0.05 \%$ w/v Triton X-114; $40^{\circ} \mathrm{C}$. 


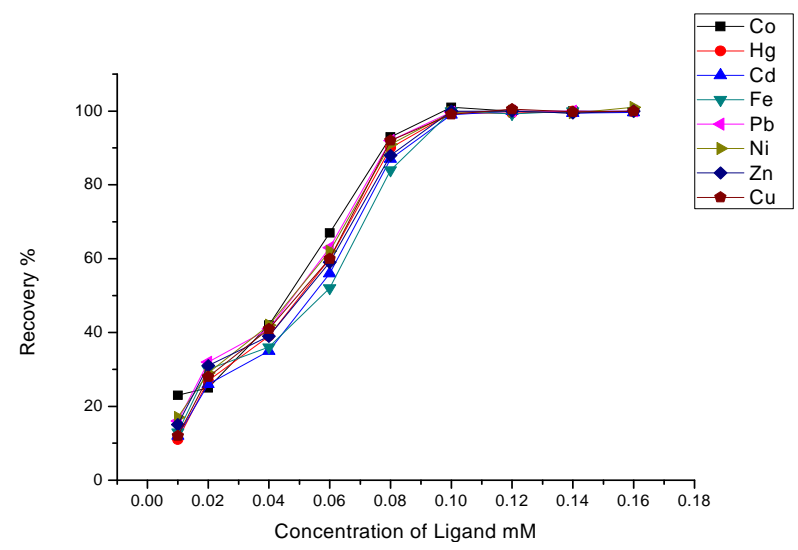

Figure 2. Effect of the ligand concentration on the recovery of extraction for the metal ions. Conditions: $10 \mathrm{ng} \cdot \mathrm{mL}^{-1}$ each metal; $\mathrm{pH}, 8 ; 50 \mathrm{~mL}$ cold aqueous solution; $0.05 \% \mathrm{w} / \mathrm{v}$ Triton X-114; $40^{\circ} \mathrm{C}$.

\subsection{Effect of Triton $\mathrm{X}-114$ Concentration}

The non-ionic surfactant, Triton X-114, was chosen because of its commercial availability in a high purified homogeneous form, low toxicological properties and cost. Also, the high density of the surfactant rich phase facilitates phase separation by centrifugation. Additionally, the cloud point $\left(23^{\circ} \mathrm{C}-26^{\circ} \mathrm{C}\right)$ of Triton X-114 permits its use in the extraction and/or preconcentration of a large number of molecules and chelates. The variation of the recoveries as a function of the concentration of Triton $\mathrm{X}-114$ in the range of 0.01 to $0.1 \%(\mathrm{w} / \mathrm{v})$ is shown in Figure 3. A concentration of $0.05 \%(\mathrm{w} / \mathrm{v})$ was chosen as optimum concentration for the extraction of the all metal ions. At lower concentrations, the extraction recovery of the complex is low probably because of the inadequacy of the assemblies to entrap the hydrophobic complex quantitatively.

\subsection{Effect of the Equilibration Temperature and the Centrifugation Time}

In order to optimize the method, it was necessary to examine the effect of the temperature on cloud-point extraction. It was desirable to employ the lowest possible equilibration temperature and the shortest incubation time of extraction for efficient separation. For this purpose, the effect of temperature and equilibration time on the extraction recovery was investigated in the range of $30^{\circ} \mathrm{C}-90^{\circ} \mathrm{C}$ and $5-35 \mathrm{~min}$, respectively, while keeping all other parameters constant. It is desirable to employ low equilibration temperature, as a compromise between the completion of extraction and efficient separation of phases. Excellent recovery was found at $40^{\circ} \mathrm{C}-60^{\circ} \mathrm{C}$. Above this temperature, reduction of extraction efficiency was noted. Therefore, $40^{\circ} \mathrm{C}$ was chosen for the

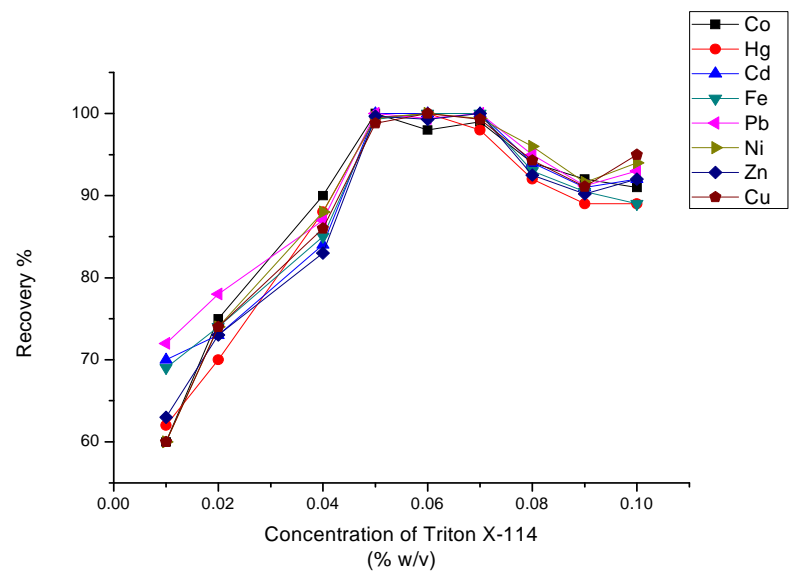

Figure 3. Effect of Triton X-114 concentration on the recovery of extraction for the metal ions. Conditions: 10 $\mathrm{ng} \cdot \mathrm{mL}^{-1}$ each metals; $\mathrm{pH}$ 8; $50 \mathrm{~mL}$ cold aqueous solution; $10^{-4} \mathrm{~mol} \cdot \mathrm{L}^{-1}$ of the ligand

equilibration temperature. The results also show that incubation time of $10 \mathrm{~min}$ is adequate to achieve the highest extraction efficiency.

\subsection{Effect of Centrifugation Time and Rate}

Generally, centrifugation time and rate ever affect micelle formation but accelerate the separation. The effect of the centrifugation time on the extraction efficiency was studied in the time range of $5.0-25.0 \mathrm{~min}$ at 4000 $\mathrm{rpm}$. A centrifugation time of $10.0 \mathrm{~min}$ was selected, since the analyte extraction is almost quantitative. No appreciable improvements were observed for longer times.

\subsection{Effect of Ionic Strength}

The cloud point of micellar solutions can be controlled by addition of salts, alcohols, nonionic surfactants and some organic compounds (salting-out effects). To date, most of the studies conducted have shown that ionic strength has no appreciable effect on the extraction efficiency. An increase in the ionic strength in the cloud point extraction does not seriously alter the efficiency of extraction of the chemical forms. Moreover, the addition of a salt can markedly facilitate the phase-separation process, as demonstrated with some nonionic surfactant system, since it alters the density of the bulk aqueous phase [24]. In our study, it was observed that the addition of KI within the interval of $0.1-1.0 \mathrm{~mol} / \mathrm{L}$ had no significant effect on the cloud point extraction efficiency.

\subsection{Effect of Methanol}

Since the surfactant-rich phase obtained after the cloud point preconcentration contains a high concentration of 
Triton X-114 and, at the same time, the volume obtained is rather small $(0.5 \mathrm{~mL})$, absolute methanol/conc. $\mathrm{HNO}_{3}$ mixture (5:1) was added to the surfactant rich phase after phase separation. Moreover, it was necessary to decrease the viscosity of the rich phase without excessive dilution of the micelle to facilitate the introduction of the sample into the atomizer of the spectrometer. There is an optimum volume $(1 \mathrm{~mL})$ with respect to the metal ion recovery. Larger volumes of acidified methanol dilution are clearly predominated resulting in a gradual absorbance reduction. One $\mathrm{mL}$ volume of methanol was therefore used throughout the remaining experiments.

\subsection{Analytical Characteristic of the Method}

The characteristics of the proposed cloud point extraction procedure for $\mathrm{Co}(\mathrm{II}), \mathrm{Hg}(\mathrm{II}), \mathrm{Cd}(\mathrm{II}), \mathrm{Fe}(\mathrm{II}), \mathrm{Pb}(\mathrm{II}), \mathrm{Ni}(\mathrm{II})$, $\mathrm{Zn}$ (II) and $\mathrm{Cu}(\mathrm{II})$ are given in Table 3. Calibration curves were obtained using $50 \mathrm{ml}$ of the standard solution of the metal ion under the experimental conditions specified in procedure. The GFAAS signals were found to be a linear function of concentration range [0.02 $\mathrm{ng} \cdot \mathrm{mL}^{-1}$ for $\mathrm{Co}(\mathrm{II}), \mathrm{Cd}(\mathrm{II}), \mathrm{Pb}(\mathrm{II})$ and $\mathrm{Ni}(\mathrm{II}) ; 0.03$ $\mathrm{ng} \cdot \mathrm{mL}^{-1}$ for $\mathrm{Cu}(\mathrm{II}) ; 0.07 \mathrm{ng} \cdot \mathrm{mL}^{-1}$ for $\mathrm{Fe}$ (II) and $\mathrm{Zn}$ (II) to $200 \mathrm{ng} \cdot \mathrm{mL}^{-1}$ for all ions], while the linear concentration range of HGAAS was 0.02 to $150 \mathrm{ng} \cdot \mathrm{mL}^{-1}$ for $\mathrm{Hg}(\mathrm{II})$. Table 3 gives the parameters of the calibration curves and the relative standard deviations (RSD) obtained for 3 replicates subjected to the complete procedure. The correlation coefficient $(r)$ of the calibration curves are within 0.990 to 0.999 , which indicates good linearity in the studied concentration range.

The limits of detection (LOD) were calculated as three times (3s) of standard deviation of blank signal by 7 replicate measurements. All the metals achieved very low detection limits in the range of $0.0165-0.094$ and is better than the previous procedures (Table 4); indicating the high sensitivity of HCPTS to the investigated metal ions.

The preconcentration factor for all metal ions were calculated by dividing the aqueous phase volume to the final volume of preconcentrated phase is 50 , while the enrichment factor as the ratio of slope of the calibration curve obtained from preconcentrated samples to that obtained without preconcentration for $\mathrm{Cu}(\mathrm{II}), \mathrm{Ni}(\mathrm{II}), \mathrm{Zn}(\mathrm{II})$, $\mathrm{Cd}(\mathrm{II}), \mathrm{Co}(\mathrm{II}), \mathrm{Pb}(\mathrm{II}), \mathrm{Fe}(\mathrm{II})$, and $\mathrm{Hg}$ (II), were 43, 51, 41, $46,54,40,45$ and 52 , respectively. This indicates that the extraction using the proposed procedure is quantitative for all metal ions. Furthermore, the determination of $\mathrm{Cu}(\mathrm{II}), \mathrm{Ni}(\mathrm{II}), \mathrm{Zn}(\mathrm{II}), \mathrm{Cd}(\mathrm{II}), \mathrm{Co}(\mathrm{II}), \mathrm{Pb}(\mathrm{II}), \mathrm{Fe}(\mathrm{II})$, and $\mathrm{Hg}$ (II) by the proposed method was compared with other CPE-AAS or CPE-ICP methods [12,15,34-38] and the results are summarized in Table 4. As it can be seen the proposed method has higher preconcentration factor and lower LOD.

\subsection{Effect of Interfering Ions}

Under the optimized conditions determined for this study, the percentage removal of $20 \mathrm{ng} \cdot \mathrm{mL}^{-1}$ of $\mathrm{Cu}(\mathrm{II}), \mathrm{Ni}(\mathrm{II})$, $\mathrm{Zn}(\mathrm{II}), \mathrm{Cd}(\mathrm{II}), \mathrm{Co}(\mathrm{II}), \mathrm{Pb}(\mathrm{II}), \mathrm{Fe}(\mathrm{II})$, and $\mathrm{Hg}(\mathrm{II})$ were studied in the presence of high concentrations of various cations and anions. All of the cations were used as their chlorides or sulfates, whereas the anions were used as the corresponding sodium salts. An ion was considered to be an interferent when it caused a variation greater than $\pm 5 \%$ in the absorbance of the sample. The corresponding results obtained are listed in Table 5. The results obtained indicates that the removal of $\mathrm{Cu}(\mathrm{II}), \mathrm{Ni}(\mathrm{II}), \mathrm{Zn}(\mathrm{II})$, $\mathrm{Cd}(\mathrm{II}), \mathrm{Co}(\mathrm{II}), \mathrm{Pb}(\mathrm{II}), \mathrm{Fe}(\mathrm{II})$, and $\mathrm{Hg}(\mathrm{II})$ ions was quantitative in all cases. Moreover, 1000 fold of $\left(\mathrm{K}^{+}, \mathrm{Na}^{+}, \mathrm{Cl}^{-}\right.$, $\mathrm{NO}_{3}^{-}, \mathrm{SO}_{4}^{2-}$ ); 750 fold of (Citrate Thiocyanate Thiourea Thiosulphate Acetate); 500 fold of $\left(\mathrm{Ca}^{2+}, \mathrm{Mg}^{2+}, \mathrm{Ba}^{2+}\right.$, $\mathrm{Sr}^{2+}$, oxalate, phosphate, $\left.\mathrm{I}^{-}\right)$and 50 fold of $\left(\mathrm{Mn}^{2+}, \mathrm{B}^{3+}\right.$, $\left.\mathrm{Al}^{3+}, \mathrm{Bi}^{3+}\right)$ have no effect on the extraction efficiency.

Table 3. Analytical characteristic of the method.

\begin{tabular}{|c|c|c|c|c|c|c|c|c|}
\hline Parameter & $\mathrm{Cu}(\mathrm{II})$ & $\mathrm{Ni}(\mathrm{II})$ & Zn(II) & Cd(II) & Co(II) & $\mathbf{P b}(\mathrm{II})$ & $\mathrm{Fe}(\mathrm{II})$ & Hg(II) \\
\hline Limit of detection $\left(\mathrm{ng} \cdot \mathrm{ml}^{-1}\right)$ & 0.019 & 0.094 & 0.0514 & 0.052 & 0.0165 & 0.047 & 0.068 & 0.041 \\
\hline Reliability (\% RSD, n=7) & 3.35 & 2.61 & 3.14 & 1.64 & 2.19 & 3.61 & 4.1 & 2.76 \\
\hline Linearity & $0.03-200$ & $0.02-200$ & $0.07-200$ & $0.02-200$ & $0.02-200$ & $0.02-200$ & $0.07-200$ & $0.02-150$ \\
\hline Slope of Calibration Curve & 0.0069 & 0.0087 & 0.0154 & 0.0624 & 0.0049 & 0.0027 & 0.0068 & 0.0141 \\
\hline Intercept of Calibration curve & $3 \times 10^{-5}$ & $3 \times 10^{-5}$ & $3 \times 10^{-5}$ & 0.0038 & $7 \times 10^{-6}$ & $9 \times 10^{-5}$ & $10^{-6}$ & 0.0002 \\
\hline Correlation coefficient $(r)$ & 0.996 & 0.995 & 0.993 & 0.999 & 0.991 & 0.990 & 0.982 & 0.993 \\
\hline Enrichment Factor (EF) & 43 & 51 & 41 & 46 & 54 & 40 & 45 & 52 \\
\hline
\end{tabular}


Table 4. CPE applications for metal ions analysis of previous studies.

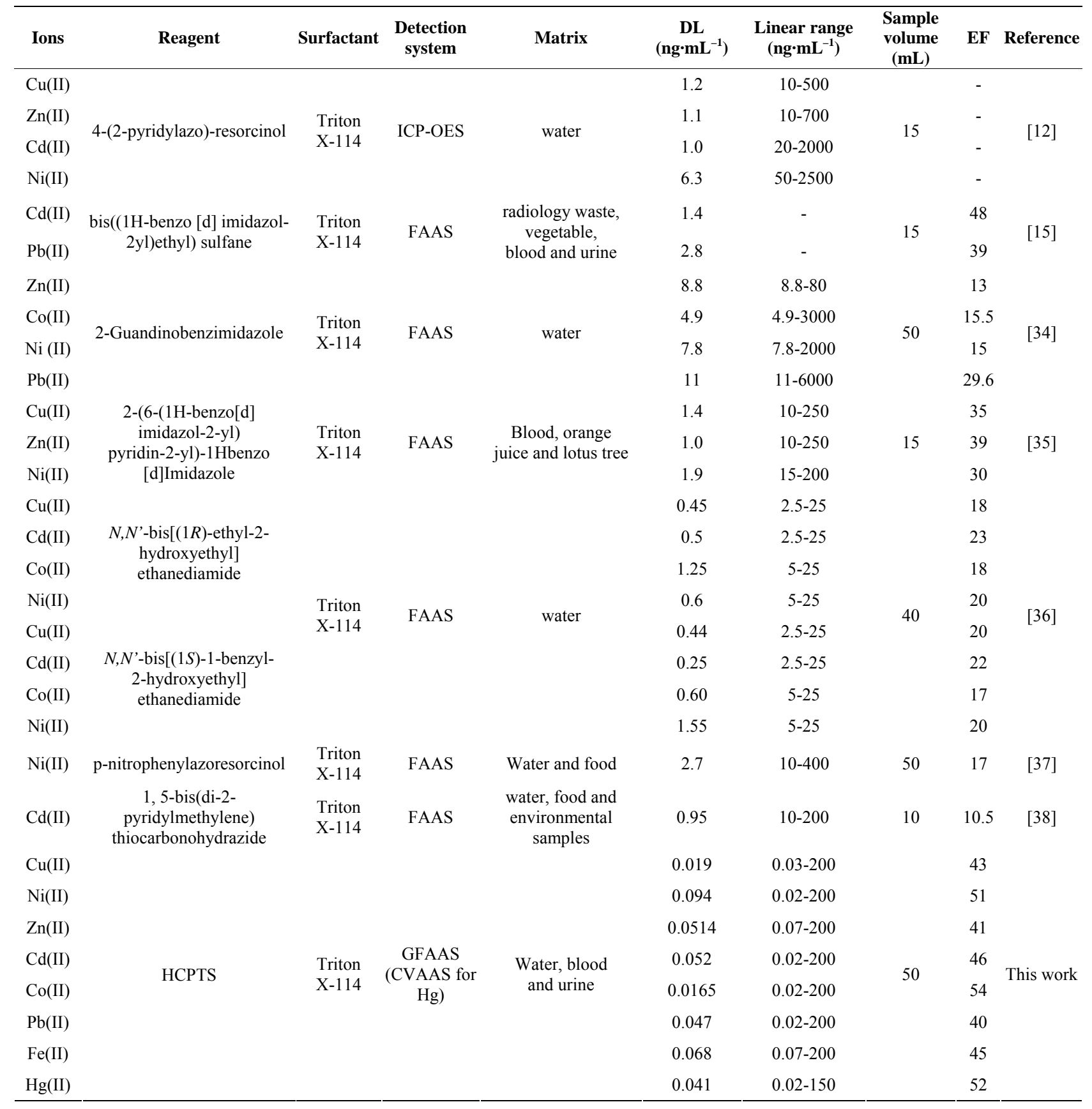

Table 5. Tolerance limits of interfering ions.

\begin{tabular}{|c|c|c|c|c|c|c|c|c|c|}
\hline \multirow{2}{*}{ Interfering ion } & \multirow{2}{*}{$\begin{array}{l}\text { Tolerance } \\
\text { limit }\end{array}$} & \multicolumn{8}{|c|}{ Recovery \% } \\
\hline & & $\mathrm{Cu}(\mathrm{II})$ & $\mathrm{Ni}(\mathrm{II})$ & $\mathrm{Zn}(\mathrm{II})$ & Cd(II) & Co(II) & $\mathbf{P b}(\mathrm{II})$ & $\mathrm{Fe}(\mathrm{II})$ & Hg(II) \\
\hline $\mathrm{K}^{+}, \mathrm{Na}^{+}, \mathrm{Cl}^{-}, \quad \mathrm{NO}_{3}^{-}, \mathrm{SO}_{4}^{2-}$ & 1000 & $99.7 \pm 0.8$ & $96.1 \pm 2.1$ & $97.2 \pm 1.8$ & $99.2 \pm 1.5$ & $98.4 \pm 1.6$ & $97.8 \pm 2.4$ & $98.1 \pm 2.4$ & $99.3 \pm 3.2$ \\
\hline $\begin{array}{c}\text { Citrate, Thiocyanate, Thiourea, } \\
\text { Thiosulphate, Acetate }\end{array}$ & 750 & $96.2 \pm 1.2$ & $99.4 \pm 1.8$ & $100.2 \pm 1.6$ & $100 \pm 1.1$ & $100 \pm 1.5$ & $98.1 \pm 0.8$ & $96.9 \pm 1.9$ & $98.4 \pm 1.8$ \\
\hline $\begin{array}{l}\mathrm{Ca}^{2+}, \mathrm{Mg}^{2+}, \mathrm{Ba}^{2+}, \mathrm{Sr}^{2+} \\
\text { Oxalate, Phosphate, } \mathrm{I}^{-}\end{array}$ & 500 & $100.4 \pm 0.6$ & $99.2 \pm 2.3$ & $98.3 \pm 2.4$ & $100.3 \pm 2.1$ & $98.2 \pm 2.2$ & $98.6 \pm 1.6$ & $96.2 \pm 2.2$ & $99.2 \pm 2.1$ \\
\hline $\mathrm{Mn}^{2+}, \mathrm{B}^{3+}, \mathrm{Al}^{3+}, \mathrm{Bi}^{3+}$ & 50 & $97 \pm 1.6$ & $98.4 \pm 0.9$ & $97.4 \pm 1.7$ & $97.8 \pm 3.1$ & $100.1 \pm 2.2$ & $96.7 \pm 0.7$ & $98.7 \pm 1.9$ & $97.6 \pm 1.9$ \\
\hline
\end{tabular}


Table 6. Recovery of trace metal ions from spiked real samples after application of presented procedure.

\begin{tabular}{|c|c|c|c|c|}
\hline Sample & Ion & Added $\left(\mathrm{ng} \cdot \mathrm{mL}^{-1}\right)$ & Found (ng.mL $\left.L^{-1}\right)$ & Recovery \% \\
\hline \multirow{16}{*}{ Tap Water } & \multirow{2}{*}{$\mathrm{Cu}$} & - & 2.1 & \multirow[b]{2}{*}{105} \\
\hline & & 1.0 & 3.15 & \\
\hline & \multirow{2}{*}{$\mathbf{N i}$} & - & 1.09 & \multirow[b]{2}{*}{95} \\
\hline & & 1.0 & 2.04 & \\
\hline & \multirow[b]{2}{*}{ Zn } & - & 0.54 & \multirow[b]{2}{*}{97} \\
\hline & & 1.0 & 1.51 & \\
\hline & \multirow{2}{*}{ Cd } & - & 0.12 & \multirow[b]{2}{*}{96} \\
\hline & & 1.0 & 1.08 & \\
\hline & \multirow{2}{*}{ Co } & - & 0.29 & \multirow[b]{2}{*}{103} \\
\hline & & 1.0 & 1.32 & \\
\hline & \multirow{2}{*}{$\mathbf{P b}$} & - & 1.7 & \multirow[b]{2}{*}{96} \\
\hline & & 1.0 & 2.66 & \\
\hline & \multirow{2}{*}{$\mathbf{F e}$} & - & 32.6 & \multirow[b]{2}{*}{105} \\
\hline & & 10.0 & 43.1 & \\
\hline & \multirow{2}{*}{ Hg } & - & 0.2 & \multirow[b]{2}{*}{96} \\
\hline & & 1.0 & 1.16 & \\
\hline \multirow{14}{*}{ Blood } & \multirow{2}{*}{$\mathrm{Cu}$} & - & 924 & \multirow[b]{2}{*}{103} \\
\hline & & 100 & 1027 & \\
\hline & \multirow{2}{*}{$\mathbf{N i}$} & - & 0.84 & \multirow[b]{2}{*}{102} \\
\hline & & 1.0 & 1.86 & \\
\hline & 7n & - & 5,579 & \\
\hline & Zn & 1000 & 6591 & 101 \\
\hline & $C_{d}$ & - & 0.92 & \\
\hline & ca & 1.0 & 1.90 & 98 \\
\hline & Co & - & 0.12 & \\
\hline & & 1.0 & 1.11 & 99 \\
\hline & Pb & - & 55.6 & \\
\hline & $\mathbf{P b}$ & 10.0 & 65.8 & 102 \\
\hline & Fe & - & 556 & \\
\hline & $\mathrm{Fe}$ & 100 & 660 & 104 \\
\hline & Ha & - & 2.43 & \\
\hline & $\mathrm{Hg}$ & 1.0 & 3.44 & 101 \\
\hline & $C_{u}$ & - & 34.8 & \\
\hline & cu & 10.0 & 45.1 & 103 \\
\hline & $\mathrm{Ni}$ & - & 2.45 & \\
\hline & & 1.0 & 3.46 & 101 \\
\hline & $7 n$ & - & 375 & \\
\hline & $\mathbf{Z n}$ & 100 & 478 & 103 \\
\hline & $\mathrm{Cd}$ & - & 0.84 & \\
\hline Urine & ca & 1.0 & 1.85 & 101 \\
\hline & $\Gamma_{0}$ & - & 1.21 & \\
\hline & Co & 1.0 & 2.20 & 99 \\
\hline & $\mathbf{P b}$ & - & 9.6 & \\
\hline & PD & 10.0 & 19.8 & 102 \\
\hline & Fe & - & 152 & \\
\hline & Fe & 100 & 255 & 103 \\
\hline & $\mathrm{Ho}$ & - & 2.13 & \\
\hline & $\mathrm{Hg}$ & 1.0 & 3.15 & 102 \\
\hline
\end{tabular}




\subsection{Accuracy and Precision}

To check the applicability, reliability and accuracy of the studied separation method, the proposed procedure has been applied to determine $\mathrm{Cu}(\mathrm{II}), \mathrm{Ni}(\mathrm{II}), \mathrm{Zn}(\mathrm{II}), \mathrm{Cd}(\mathrm{II})$, $\mathrm{Co}(\mathrm{II}), \mathrm{Pb}$ (II), $\mathrm{Fe}(\mathrm{II})$, and $\mathrm{Hg}(\mathrm{II})$ ions in spiked tap water, blood and urine samples. The results are presented in Table 6. The recovery values were around $100 \%$ in the different samples. This indicates the capability of the method in the determination of analytes in real samples with high efficiency. In order to establish the validity of the proposed method, the described procedure was applied for the determination of investigated ions in multielement standard solution 70006 (Fluka). The obtained results assembled in Table 7 are in very good agreement with the labeled values. The error of determination does not exceed $1.5 \%$.

\subsection{Analysis of Real Water Samples}

The CPE method was applied for the preconcentration and separation of $\mathrm{Cu}(\mathrm{II}), \mathrm{Ni}(\mathrm{II}), \mathrm{Zn}(\mathrm{II}), \mathrm{Cd}(\mathrm{II}), \mathrm{Co}(\mathrm{II})$, $\mathrm{Pb}(\mathrm{II}), \mathrm{Fe}(\mathrm{II})$ and $\mathrm{Hg}(\mathrm{II})$ in different water samples. Surface water samples were collected from Nile River at Mansoura, Miet Antar, Sherbin, and Faraskour; brackish water at Damietta bridge, Elgerbi, Ezbet Elborg and Elmanzalah lake and Mediterranean Sea at Port Fouad and Port Said. Table 8 shows the results of the application process in comparison with the standard methods: direct HGAAS in the case of $\mathrm{Hg}$ (II) and solvent extraction (ammonium pyrrolidinedithiocarbamate in methyl isobutyl ketone) followed by ICP-MS determination in the case of the other metal ions [39]. It can be concluded that the concentration of the investigated metal ions increases obviously in the region beginning from Damietta Bridge to the River effluent and in Elmanzalah Lake. This may be attributed to the domestic and anthropogenic activities in these regions which are also shown in the water quality and nutrients measurements. It can be also concluded that the concentrations of heavy metal ions are within the permissible levels and are in agreement with those reported previously [39-41].

\subsection{Analysis of the Metals in Blood of Hemodialysis Patients}

Finally, the metal ions under investigation were determined in 13 hemodialysis patients and 11 matched healthy persons (control group). For statistical calculations we used SPSS-PC software, version 8 (MAS Medical \& Scientific Eq. Co, IL, USA). Differences between groups were tested with the $\mathrm{t}$-test for independent samples. Correlation between variables was assessed with Spearman's rank correlation coefficient $(r)$. A probability value $(p)$ less than 0.05 was considered to be significant. The results summarized in Table 9 show that the hemodialysis patients had normal blood levels of Co, $\mathrm{Ni}$ and $\mathrm{Hg}$. The blood levels of $\mathrm{Cu}, \mathrm{Zn}$ and $\mathrm{Fe}$ were significantly lower than the normal group. However, the levels of $\mathrm{Cd}$ and $\mathrm{Pb}$ were higher than the control group. These findings indicated that hemodialysis patients suffer from deficiency of some essential metals as well as they are at high risk to some toxic metals.

\section{Conclusions}

The developed CPE procedure is simple, rapid, safe and provide high preconcentration factor and low detection limits for the determination of ultra trace levels $\mathrm{Cu}(\mathrm{II})$, $\mathrm{Ni}(\mathrm{II}), \mathrm{Zn}(\mathrm{II}), \mathrm{Cd}(\mathrm{II}), \mathrm{Co}(\mathrm{II}), \mathrm{Pb}(\mathrm{II}), \mathrm{Fe}(\mathrm{II})$, and $\mathrm{Hg}(\mathrm{II})$

Table 7. Determination of metal ions in multielement standard solution $70006(n=3)$.

\begin{tabular}{|c|c|c|}
\hline Metal ion & Found by present method $\left(\mathrm{mg} \cdot \mathrm{L}^{-1}\right)$ & Certified value $\left(\mathbf{m g} \cdot \mathbf{L}^{-1}\right)$ \\
\hline $\mathrm{Cu}(\mathrm{II})$ & $19.8 \pm 1.1$ & 20 \\
\hline $\mathrm{Ni}(\mathrm{II})$ & $20.2 \pm 0.9$ & 20 \\
\hline $\mathrm{Zn}(\mathrm{II})$ & $98.7 \pm 2.2$ & 100 \\
\hline $\mathrm{Cd}(\mathrm{II})$ & $10.05 \pm 0.4$ & 10 \\
\hline $\mathrm{Co}(\mathrm{II})$ & $9.87 \pm 0.3$ & 10 \\
\hline $\mathrm{Pb}(\mathrm{II})$ & $40.2 \pm 1.2$ & 40 \\
\hline $\mathrm{Fe}(\mathrm{II})$ & $100.5 \pm 1.8$ & 100 \\
\hline $\mathrm{Hg}(\mathrm{II})$ & Not detected & - \\
\hline
\end{tabular}




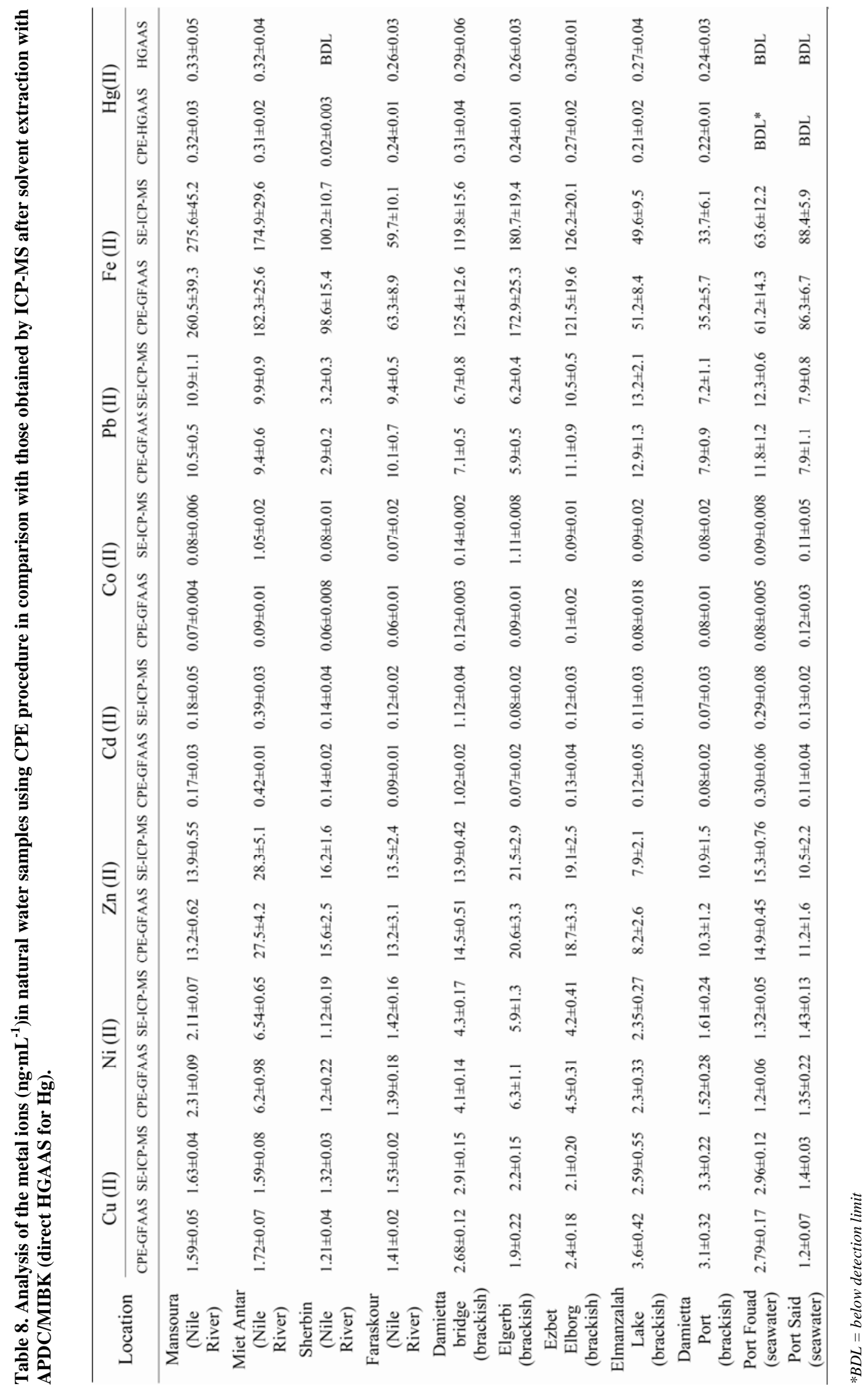


Table 9. Metal ions levels $\left(\mathrm{ng} \cdot \mathrm{mL}^{-1}\right)$ in blood of hemodialysis $(\mathrm{n}=13)$ and healthy persons $(\mathrm{n}=11)$.

\begin{tabular}{ccc}
\hline Metal & Hemodialysis patients & Normal persons \\
\hline $\mathrm{Cu}(\mathrm{II})$ & $715 \pm 195^{*}$ & $895 \pm 215$ \\
$\mathrm{Ni}(\mathrm{II})$ & $0.69 \pm 0.22$ & $0.79 \pm 0.19$ \\
$\mathrm{Zn}(\mathrm{II})$ & $3954 \pm 293^{*}$ & $5421 \pm 452$ \\
\hline
\end{tabular}

${ }^{*} \mathrm{p}<0.05$.

in water, blood and urine samples. This procedure agrees with the Green Chemistry principles.

\section{References}

[1] J. O. Duruibe, M. O. C. Ogwuegbu and J. N. Egwurugwu, "Heavy Metal Pollution and Human Biotoxic Effects," International Journal of Physical Sciences, Vol. 2, No. 5, 2007, pp. 112-118.

[2] M. Valko, H. Morris and M. Cronin, "Metals, Toxicity and Oxidative Stress," Current Medicinal Chemistry, Vol. 12, No. 10, 2005, pp. 1161-1208. doi:10.2174/0929867053764635

[3] K. Jankowski, J. Yao, K. Kasiura, A. Jackowska and A. Sieradzka, "Multielement Determination of Heavy Metals in Water Samples by Continuous Powder Introduction Microwave-Induced Plasma Atomic Emission Spectrometry after Preconcentration on Activated Carbon," Spectrochimica Acta Part B, Vol. 60, No. 3, 2005, pp. 369-375. doi:10.1016/j.sab.2004.11.002

[4] S. Ceratti, S. Moyano, J. Marrero, P. Smichowski and L. D. Martinez, "On-Line Preconcentration of Nickel on Activated Carbon Prior to Its Determination by Vapor Generation Associated to Inductively Coupled Plasma Optical Emission Spectrometry," Journal of Analytical Atomic Spectrometry, Vol. 20, No. 6, 2005, pp. 559-561. doi:10.1039/b500467p

[5] V. Umashankar, R. Radhamani, K. Ramadoss and D. S. R. Murty, "Simultaneous Separation and Preconcentration of Trace Elements in Water Samples by Coprecipitation on Manganese Dioxide Using D-Glucose as Reductant for $\mathrm{KMnO}_{4}$," Talanta, Vol. 57, No. 6, 2002, pp. 1029-1038. doi:10.1016/S0039-9140(02)00150-9

[6] G. Doner and A. Ege, "Determination of Copper, Cadmium and Lead in Seawater and Mineral Water by Flame Atomic Absorption Spectrometry after Coprecipitation with Aluminum Hydroxide," Analytica Chimica Acta, Vol. 547, No. 1, 2005, pp. 14-17. doi:10.1016/j.aca.2005.02.073

[7] M. Kumar, D. P. S. Rathore and A. K. Singh, "Preconcentration of Lead with Amberlite XAD-2 and Amberlite XAD-7 Based Chelating Resins for Its Determination by Flame Atomic Absorption Spectrometry," Talanta, Vol. 56, No. 4, 2002, pp. 735-744. doi:10.1016/S0039-9140(01)00606-3

[8] V. K. Jain, H. C. Mandalia, H. S. Gupte and D. J. Vyas, “Azocalix[4]pyrrole Amberlite XAD-2: New Polymeric Chelating Resins for the Extraction, Preconcentration and
Sequential Separation of $\mathrm{Cu}(\mathrm{II}), \mathrm{Zn}(\mathrm{II})$ and $\mathrm{Cd}(\mathrm{II})$ in Natural Water Samples," Talanta, Vol. 79, No. 5, 2009, pp. 1331-1340. doi:10.1016/j.talanta.2009.05.047

[9] M. B. Gholivand, M. Mohammadi, M. Khodadadian and M. K. Rofouei, "Novel Platinum(II) Selective Membrane Electrode Based on 1,3-bis(2-cyanobenzene)triazene," Talanta, Vol. 78, No. 3, 2009, pp. 922-928. doi:10.1016/j.talanta.2008.12.070

[10] X. G. Li, X. L. Ma and M. R. Huang, "Lead(II) Ion-Selective Electrode Based on Polyaminoanthraquinone Particles with Intrinsic Conductivity," Talanta, Vol. 78, No. 2, 2009, pp. 498-505. doi:10.1016/j.talanta.2008.11.045

[11] M. Camino, M. G. Bagur, M. Sandchez-Vinas, D. Gazquez and R. Romero, "Multivariate Optimization of Solvent Extraction of $\mathrm{Cd}(\mathrm{II}), \mathrm{Co}(\mathrm{II}), \mathrm{Cr}(\mathrm{VI}), \mathrm{Cu}(\mathrm{II})$, $\mathrm{Ni}(\mathrm{II}), \mathrm{Pb}(\mathrm{II})$ and $\mathrm{Zn}(\mathrm{II})$ as Dibenzyldithiocarbamates and Detection by AAS," Journal of Analytical Atomic Spectrometry, Vol. 16, No. 6, 2002, pp. 638-642. doi: $10.1039 / \mathrm{b} 101590 \mathrm{~g}$

[12] E. L. Silva, P. dos S. Roldan, M. F. Gin, "Simultaneous Preconcentration of Copper, Zinc, Cadmium, and Nickel in Water Samples by Cloud Point Extraction Using 4-(2Pyridylazo)-Resorcinol and Their Determination by Inductively Coupled Plasma Optic Emission Spectrometry," Journal of Hazardous Materials, Vol. 171, No. 1-3, 2009, pp. 1133-1138. doi:10.1016/j.jhazmat.2009.06.127

[13] M. Ghaedi, A. Shokrollahi, K. Niknam, E. Niknam, S. Derki and M. Soylak, "Cloud Point Extraction Procedure for Preconcentration/Flame Atomic Absorption Spectrometric Determination of Silver, Zinc, and Lead at Subtrace Levels in Environmental Samples," The Journal of AOAC International, Vol. 92, No. 3, 2009, pp. 907-913.

[14] H. Filik, T. Cengel and R. Apak, "Selective Cloud Point Extraction and Graphite Furnace Atomic Absorption Spectrometric Determination of Molybdenum (VI) Ion in Seawater Samples," Journal of Hazardous Materials, Vol. 169, No. 1-3, 2009, pp. 766-771. doi:10.1016/j.jhazmat.2009.04.017

[15] M. Ghaedi, A. Shokrollahi, K. Niknam, E. Niknam, A. Najibi and M. Soylak, "Cloud Point Extraction and Flame Atomic Absorption Spectrometric Determination Of Cadmium(II), Lead(II), Palladium(II) and Silver(I) in Environmental Samples," Journal of Hazardous Materials, Vol. 168, No. 2-3, 2009, pp. 1022-1027. doi:10.1016/j.jhazmat.2009.02.130

[16] S. Candir, I. Narin, M. Soylak, "ligandless Cloud Point Extraction of $\mathrm{Cr}(\mathrm{III}), \mathrm{Pb}(\mathrm{II}), \mathrm{Cu}(\mathrm{II}), \mathrm{Ni}(\mathrm{II}), \mathrm{Bi}(\mathrm{III})$, and Cd(II) Ions in Environmental Samples with Tween 80 
and Flame Atomic Absorption Spectrometric Determination," Talanta, Vol. 77, No. 1, 2008, pp. 289-293. doi:10.1016/j.talanta.2008.06.024

[17] E. Kilinc, A. Cetin, M. Togrul and H. Hosgoren, "Synthesis of Bis(Amino Alcohol)Oxalamides and Their Usage for the Preconcentration of Trace Metals by Cloud Point Extraction," Analytical Sciences, Vol. 24, No. 6, 2008, pp. 763-768. doi:10.2116/analsci.24.763

[18] S. Shariati, Y. Yamini and M. K. Zanjani, "Simultaneous Preconcentration and Determination of U(VI), Th(IV), $\mathrm{Zr}(\mathrm{IV})$ and $\mathrm{Hf}(\mathrm{IV})$ Ions in Aqueous Samples Using Micelle-Mediated Extraction Coupled to Inductively Coupled Plasma-Optical Emission Spectrometry," Journal of Hazardous Materials, Vol. 156, No. 1-3, 2008, pp 583590. doi:10.1016/j.jhazmat.2007.12.061

[19] A. Beiraghi and S. Babaee, "Separation and Preconcentration of Ultra Trace Amounts of Beryllium in Water Samples Using Mixed Micelle-Mediated Extraction and Determination by Inductively Coupled Plasma-Atomic Emission Spectrometry," Analatica Chimica Acta, Vol. 607, No. 2, 2008, pp. 183-190. doi:10.1016/j.aca.2007.11.028

[20] A. Ohashi, T. Hashimoto, H. Imura and K. Ohashi, "Cloud Point Extraction Equilibrium of Lanthanum(III), Europium(III) and Lutetium(III) Using Di(2-Ethylhexyl) Phosphoric Acid and Triton X-100," Talanta, Vol. 73, No. 5, 2007, pp. 893-898. doi:10.1016/j.talanta.2007.05.012

[21] N. Shokoufi and F. Shemirani, "Laser Induced-Thermal Lens Spectrometry after Cloud Point Extraction for the Determination of Trace Amounts of Rhodium," Talanta, Vol. 73, No. 4, 2007, pp. 662-667. doi:10.1016/i.talanta.2007.04.035

[22] Y. Li and B. Hu, "Cloud Point Extraction with/without Chelating Agent on-Line Coupled with Inductively Coupled Plasma Optical Emission Spectrometry for the Determination of Trace Rare Earth Elements in Biological Samples," Journal of Hazardous Materials, Vol. 174, No. 1-3, 2010, pp. 534-540. doi:10.1016/j.jhazmat.2009.09.084

[23] P. Anastas and N. Eghbali, "Green Chemistry: Principles and Practice," Chemical Society Reviews, Vol. 39, No. 1, 2010, pp. 301-312. doi:10.1039/b918763b

[24] C. B. Ojeda and F. S. Rojas, "Separation and Preconcentration by a Cloud Point Extraction Procedure for Determination of Metals: An Overview," Analytical and Bioanalytical Chemistry, Vol. 394, No. 3, 2009, pp. 759-782. doi:10.1007/s00216-009-2660-9

[25] F. H. Quina and W. L. Hinze, "Surfactant-Mediated Cloud Point Extractions: An Environmentally Benign Alternative Separation Approach," Industrial \& Engineering Chemistry Research, Vol. 38, No. 11, 1999, pp. 41504168. doi:10.1021/ie980389n

[26] B. A. Gingras, R. L. Somorjai and C. H. Bayley, "The Preparation of Some Thiosemicarbazones and Their Copper Complexes," Canadian Journal of Chemistry, Vol. 39, No. 5, 1961, pp. 973-985. doi:10.1139/v61-122

[27] A. A. Abu-Hussen and W. Linert, "Redox, Thermodynamic and Spectroscopic of Some Transition Metal
Complexes Containing Heterocyclic Schiff Base Ligands," Spectrochimica Acta A Molecular and Biomolecular Spectroscopy, Vol. 74, No. 1, 2009, pp. 214223.

[28] M. M. Hassanien, I. M. Gabr, M. H. Abdel-Rhman and A. A. El-Asmy, "Synthesis and Structural Investigation of Monoand Polynuclear Copper Complexes of 4-Ethyl-1(Pyridin-2-Yl) Thiosemicarbazide" Spectrochimica Acta A Molecular and Biomolecular Spectroscopy, Vol. 71, No. 1, 2008, pp. 73-79.

[29] A. A. El-Asmy, M. M. Hassanian, M. H. Abdel-Rhman and I. M. Gabr, "Synthesis, Characterization and AntibacTerial Activity of $\mathrm{Pd}(\mathrm{II}), \mathrm{Pt}(\mathrm{II})$ and $\mathrm{Ag}(\mathrm{I})$ Complexes of 4-ethyl and 4-(p-tolyl)-1-(pyridin-2-yl)thiosemicarbazides," Journal of Sulfur Chemistry, Vol. 31, No. 2, 2010, pp. 141-151. doi:10.1080/17415990903569569

[30] S. A. Ahmed, "Alumina Physically Loaded by Thiosemicarbazide for Selective Preconcentration of Mercury(II) Ion from Natural Water Samples," Journal of Hazardous Materials, Vol. 156, No. 1-3, 2008, pp. 521529. doi:10.1016/j.jhazmat.2007.12.049

[31] R. Gao, Z. Hu, X. Chang, Q. He , L. Zhang, Z. Tu and J. Shi, "Chemically Modified Activated Carbon with 1-acylthio-semicarbazide for Selective Solid-Phase Extraction and Preconcentration of Trace $\mathrm{Cu}(\mathrm{II}), \mathrm{Hg}(\mathrm{II})$ and $\mathrm{Pb}$ (II) from Water Samples" Journal of Hazardous Materials, Vol. 172, No. 1, 2009, pp. 324-329. doi:10.1016/j.jhazmat.2009.07.014

[32] M. E. Mahmoud, A. A. Yakout, S. B. Ahmed, M. M. Osman, "Speciation, Selective Extraction and Preconcentration of Chromium Ions via Alumina-FunctionalizedIsatin-Thiosemicarbazone," Journal of Hazardous Materials, Vol. 158, No. 2-3, 2008, pp. 541-548. doi:10.1016/j.jhazmat.2008.01.114

[33] M. M. Hassanien, M. H. Abdel-Rhman and A. A. ElAsmy, "Cloud Point Extraction and Spectrophotometric Determination of $\mathrm{Cu}(\mathrm{II})$ in Saturated Saline Solutions Using 4-ethyl-1-(pyridin-2-yl) Thiosemicarbazide," Transition, Metal Chemistry, Vol. 32, No. 8, 2007, pp. 10251029. doi:10.1007/s11243-007-0281-8

[34] N. Dallali, M. M. Zahedi and Y. Yamini, "Simultaneous Cloud Point Extraction and Determination of $\mathrm{Zn}, \mathrm{Co}, \mathrm{Ni}$ and $\mathrm{Pb}$ by Flame Atomic Absorption Spectrometry, Using 2-Guani-Dinobenzimidazole as the Complexing Agent," Scientia Iranica, Vol. 14, No. 4, 2007, pp. 291-296.

[35] M. Ghaedi, K. Niknam, E. Niknamb and M. Soylak, "Application of Cloud Point Extraction for Copper, Nickel, Zinc and Iron Ions in Environmental Samples," Journal of the Chinese Chemical Society, Vol. 56, No. 5, 2009, pp. 981-986.

[36] E. Kilinc, A. Cetin, M. Togrul and H. Hosgoren, "Synthesis of Bis(Amino Alcohol) Oxalamides and Their Usage for the Preconcentration of Trace Metals by Cloud Point Extraction," Analytical Sciences, Vol. 24, No. 6, 2008, pp. 763-768. doi:10.2116/analsci.24.763

[37] C. A. Şahin, M. Efeçınar and N. Şatıroğlu, "Combination of Cloud Point Extraction and Flame Atomic Absorption Spectrometry for Preconcentration and Determination of 
Nickel and Manganese Ions in Water and Food Samples," Journal of Hazardous Materials, Vol. 176, No. 1-3, 2010, pp. 672-677. doi:10.1016/j.jhazmat.2009.11.084

[38] C. B. Ojeda, F. S. Rojas and J. M. Pavón, "Preconcentration of Cadmium in Environmental Samples by Cloud Point Extraction and Determination by FAAS," American Journal of Analytical Chemistry, Vol. 1, No. 3, 2010, pp. 127-134. doi:10.4236/ajac.2010.13016

[39] M. M. Hassanien, "Silica Glass Modified with Flavonoid Derivatives for Preconcentration of Some Toxic Metal Ions in Water Samples and Their Determination with ICP-MS," Environmental Monitoring and Assessment, Vol. 167, No. 1-4, 2010, pp. 587-598. doi:10.1007/s10661-009-1075-6
[40] K. Abou-El-Sherbini, I. M. Kenawy, R. M. Issa, M. A. Hamed and R. Elmorsi, "Separation and Preconcentration in a Batch Mode of Cd(II), Cr(III, VI), Cu(II), Mn(II, VII) and $\mathrm{Pb}(\mathrm{II})$ by Solidphase Extraction by Using of Silica Modified with N-Propylsalicylaldimine," Talanta, Vol. 58, No. 2, 2002, pp. 289-300. doi:10.1016/S0039-9140(02)00248-5

[41] I. M. Kenawy, M. A. Hafez, M. A. Akl and R. R. Lashein, "Determination by AAS of Some Trace Heavy Metal Ions in Some Natural and Biological Samples after Their Preconcentration Using Newly Chemically Modified Chloromethylated Polystyrene-PAN Ion-Exchanger," Analytical Sciences, Vol. 16, No. 5, 2000, pp. 493-500. $\underline{\text { doi:10.2116/analsci.16.493 }}$ 